ро н лізов но дин міку т суч сний ст н торговельно-економічних зв’язків кр їни з кр їн ми . озглянуто головні п р метри, структурні особливості, геогр фічні н прями розвитку зовнішньоторговельних зв'язків кр їни з кр їн ми , т кож виділено головні проблеми в р мк х співробітництв кр їни з цими кр їн ми.

лючові слов : кр їни-уч сниці , торгівельно-економічні зв'язки, торгівля тов р ми, торгівля послуг ми, обсяги експорту, імпорту, тов рообігу, с льдо зовнішньої торгівлі тов р ми т послуг ми, інвестиції.

йв жливішим пріоритетом кр їни в р мк х вз ємодії з кр н ми повинен бути економічний пріоритет, який грунтується, н с мперед, н вигідних двосторонніх умов х співпр ці з кр їн ми-уч сницями . ротягом дв дцятирічного існув ння

, н ж ль, не було простежено спільної стр тегії щодо вирішення економічних проблем кр їн-уч сниць т єдиної моделі міждерж вних економічних зв'язків, інтегр ційних процесів тощо. ерешкодою цьому $є$ різн зовнішньополітичн т зовнішньоекономічн орієнт ція кр їн, різний рівень їхнього соці льно-економічного розвитку, тініз ція т низьк диверсифік ція економік, висок з лежність економік від імпорту, т кож те, що зн чною ч стиною свого експорту кр їни виступ ють по відношенню один до одного н зовнішніх ринк х як конкуренти тощо. роте кр їн, передусім, м є розгляд ти кр їни як великий ринок для експорту т імпорту б г тьох видів промислової, сільськогоспод рської продукції, енергоносіїв, сировини і м тері лів тощо.

г льноторговельний обіг кр їни з кр їн ми у 2010 р. ст новив 51,9 млрд дол. , бо 40,1\% (з 129 млрд дол світового з г льноторгівельного обігу). стк експорту т імпорту тов рів - 36,5 і 38,5 \% від з г льного обсягу (рис. 1). порівнянні, обсяги експорту т імпорту тов рів до зії ст новили - 26,6 і 16,5\%, вропи - 26,9 і 32,9 \% (у т.ч. до кр їн вропейського оюзу ( ) - 25,3 і 31,4 \%), фрики $-5,8$ і 1,4\%, мерики - 3,8 і 4,7\%, встр лії і ке нії - 0,05 і 0,4\%. ідповідно, обсяги експорту т імпорту послуг до кр їн ст новили: - 47,7 і 17,3\%, зії - 9, 1 і 22,4 \%, вропи - 28,0 і 44,4 \% (у т. ч. до кр їн $-27,1$ і 55,5\%), фрики 1,3 і $0,8 \%$, мерики - 10,5 і 10,4\%, встр лії і ке нії-0,3 і 0,0\%. тже, головним регіоном світу для кр їни в торговельно-економічних зв'язк х є кр їни, , хоч їхня ч стк в торговельному 6 л нсі 3 ост нні роки суттєво знизил ся, що можн пояснити, н с мперед, втр тою кр їни н ринк х цих кр їн своїх позицій. ростеживши дин міку експорту-імпорту тов рів кр їни з к рїн ми 3 зн чимо, що в 1996 р. ч стк експорту тов рів н ці кр їни ст новил 50,1 \% від з г льного пок зни-

(С) суляк ., 2012 
к , імпорту $-63,5 \%$, в 2010 р. ці пок зники зн чно знизились і ст новили, відповідно, $36,4 \%$ і 43,9 \% (рис. 2, 3). продовж 1996-2010 рр. пок зник зовнішньоторговельного обігу тов рів і послуг кр іни з кр ін ми збільшився з 40,6 до 51,9 млрд дол. 2010 р. с льдо зовнішньоторговельного обігу з кр їн ми було нег тивним і ст новило - 3287 млн дол.

кспорт тов рів кр їни

р їни

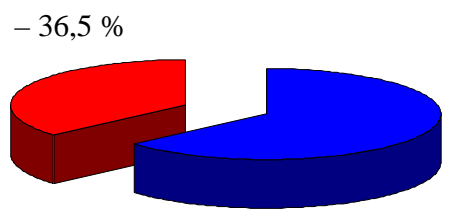

нші кр їни - 63,5\%

кспорт послуг кр їни

нші кр їни $-52,3 \%$
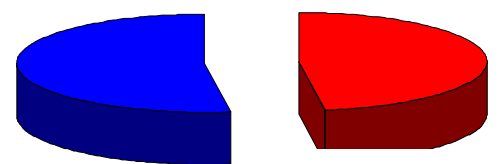

р їни мпорт тов рів кр їни

р їни

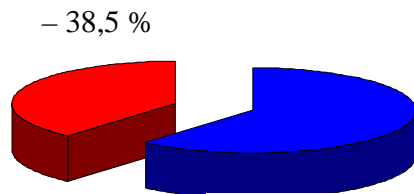

нші кр їни $-61,5 \%$

мпорт послуг кр їни

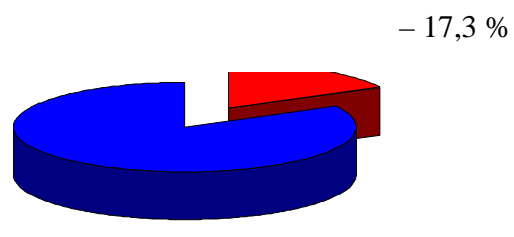

нші кр їни - 82,7 \%

ис. 1. кспорт-імпорт тов рів і послуг кр їни, 2010 p.

кр їні 2010 р. простежено н йбільше зрост ння обсягів зовнішньої торгівлі з держ в ми-уч сник ми (37 \%), експорт збільшився н $39 \%$, імпорт - н $36 \%$.

стк недорогоцінних мет лів і виробів з них у з г льному об'ємі експорту в держ виуч сники ст новил в 2010 р. $21,9 \%$ (у 2009 р. - 23,7\%), м шин, уст ткув ння і мех нізмів - 16,8 \% (21,2 \%), з собів тр нспорту - 14,7 \% (7,9 \%), мінер льних продуктів - 10,3\% (7,8 \%), готових х рчових продуктів - 9,6 \% (10,9\%), продукції хімічної і пов'яз них з нею г лузей промисловості - 8,8 \% (9,7 \%), продукції рослинного походження $-4,9 \%(5,3 \%)$. кр їн збільшил пост ч ння в держ ви-уч сники у 2010 р.: бензин втомобільний в 2,2 p 3 , дизельне п ливо - н $54 \%$, м зут - в 2,9 р з, електроенергія - в 2,3 р з, чорні мет ли - н $38 \%$, втомобілі легкові - н $81 \%$, скоротил пост ч ння зл ків н $43 \%$, к м'яного вугілля - н $54 \%$. кр їни прип д ло $86 \%$ експорту бензину втомобільного, 76 \% дизельного п лив , 34 \% м зуту, $71 \%$ електроенергії, $13 \%$ чорних мет лів, $99 \%$ легкових втомобілів. росли обсяги імпорту з кр їн до кр їни: н фти н $8 \%$, втомобільного бензину - н $31 \%$, к м'яного вугілля - н $45 \%$, чорних мет лів - н $84 \%$, втомобілів легкових - н $42 \%$; скоротився імпорт м зуту н $41 \%$, природного г зу - н $4 \%$. 3 г льному обсязі імпорту ч стк пост ч нь 3 кр їн н фти, продуктів переробки н фти (дизельного п лив і м зуту) і природного г зу ст новил $100 \%$, к м'яного вугілля $-87 \%$, чорних мет лів $-75 \%$, втомобільного бензину $-45 \%$, легкових втомобілів - $19 \%$. оловни- 
ми торговельними п ртнер ми кр їни серед кр їн

були ілорусь, 3 хст н і осія (т бл. 1).

жерелом зниження дефіциту торговельного б л нсу кр їни з кр їн ми $є$ позитивне с льдо у сфері послуг - 4,6 млрд дол., у тім числі 4,3 млрд прип д ло н осію. озитивне с льдо у торгівлі кр їни з послуг ми простежено з усім кр їн ми ідируючі позиції з йм ють (після осії) уркменіст н, ілорусь т 3 хст н. зн чимо, що хоч й обсяги експорту послуг кр їни до кр їн 3 ост нні роки збільшився, одн к н ведені пок зники не з безпечують повного покриття п сивного с льдо в торговельних відносин х кр їни з кр їн ми т усім світовим ринком.

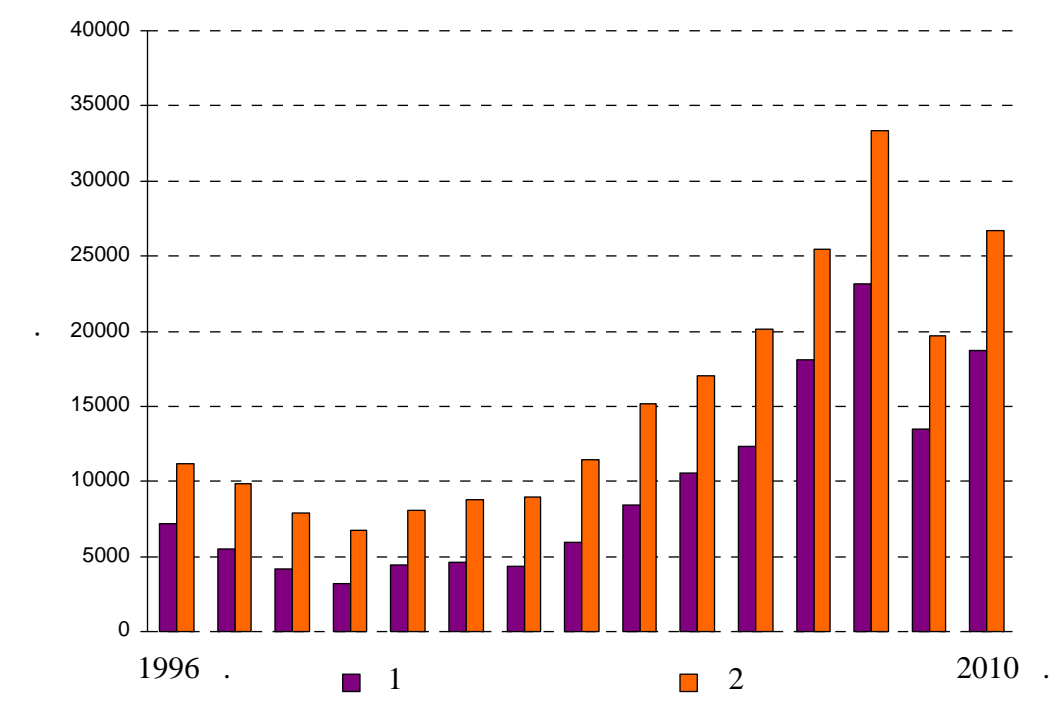

ис. 2. ин мік експорту-імпорту тов рів кр їни з кр їн ми $: 1$-експорт; 2 -імпорт.

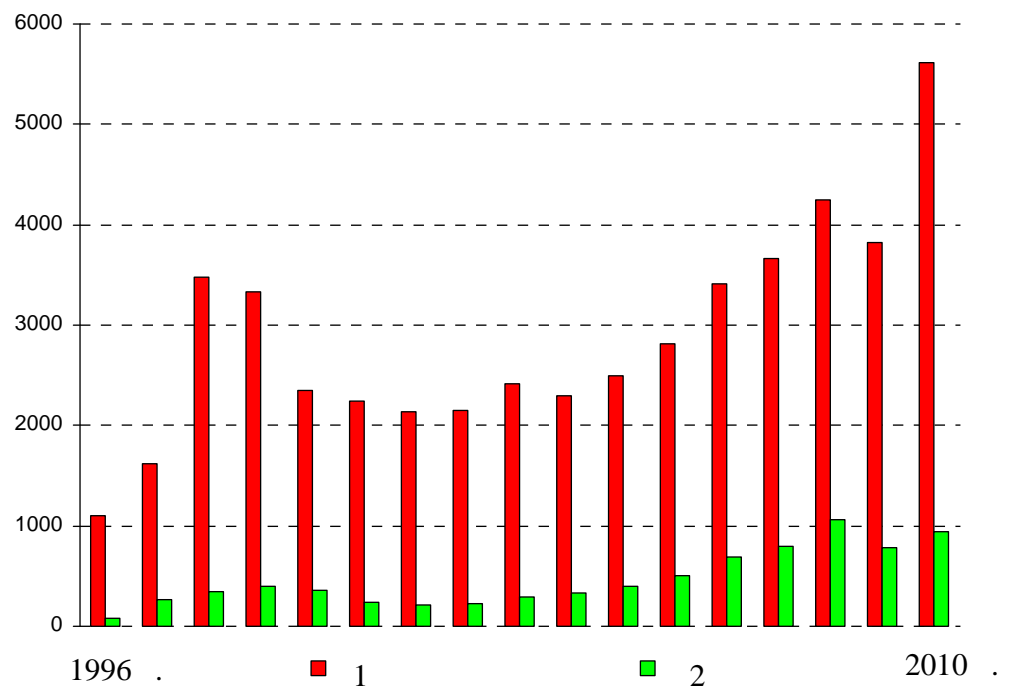

ис. 3. ин мік експорту-імпорту послуг кр їни з кр їн ми $\quad: 1$-експорт; 2 -імпорт. 
стк кр їн у структурі експроту т імпорту тов рів і послуг, \%

\begin{tabular}{|c|c|c|c|c|}
\hline \multirow{2}{*}{ р їни } & \multicolumn{2}{|c|}{ кспорт } & \multicolumn{2}{c|}{ мпорт } \\
\cline { 2 - 5 } & тов рів & послуг & тов рів & послуг \\
\hline зерб йдж н & 3,2 & 0,4 & 3,6 & 1,4 \\
\hline ілорусь & 10,1 & 2,3 & 9,6 & 6,7 \\
\hline ірменія & 1,1 & 0,3 & 0,1 & 0,8 \\
\hline х хст н & 6,9 & 1,5 & 2,9 & 2,3 \\
\hline иргист н & 0,5 & 0,05 & 0,02 & 0,2 \\
\hline олдов & 3,8 & 1,3 & 0,3 & 3,1 \\
\hline $\begin{array}{c}\text { осійськ } \\
\text { едер ція }\end{array}$ & 71,6 & 91,3 & 83,1 & 84,4 \\
\hline джикист н & 0,5 & 0,06 & 0,01 & 0,04 \\
\hline уркменіст н & 1,1 & 2,0 & 0,1 & 0,7 \\
\hline збекист н & 1,2 & 0,2 & 0,3 & 0,4 \\
\hline
\end{tabular}

ля кр їни дод тковими чинник ми перебігу т под льшого формув ння зовнішньоторговельних відносин 3 кр їн ми півдружності, зокрем 3 осійською едер цією ( ), є висок з лежність н ціон льної економіки від російських енерго-ресурсів т конкуренція з 3 ринки збуту продукції н ринк х . йбільшими експортер ми н терені були і з лиш ються осія й кр їн, ле нині осія н ринку випередж $є$ кр їну м йже з усім тов рними груп ми експорту, зокрем, т кими, як продукція чорної мет лургії, м шини, уст ткув ння тр нспортні з соби, продукція хімічної, деревообробної т целюлозно-п перової промисловості, текстильні м тері ли, текстильні й інші вироби тощо. кр їн ж перев жно посід $є$ передові позиції н цьому ринку порівняно $з$ осією лише 3 т кими тов рними груп ми, як продовольчі тов ри т сільськогоспод рськ сировин , т кож деякі види продукції чорної т кольорової мет лургії. о основних м кроекономічних індик торів, що х р ктеризують зовнішньоекономічну діяльність будь-якої кр їни, н леж ть передусім пок зники експорту т імпорту тов рів і послуг, з г льний обсяг зовнішньоторговельного обігу тов рів т послуг тощо. огляду н це в рто простежити пок зники зовнішньоторговельної діяльності кр їни з окремими кр їн ми

еред кр їн $\epsilon$ держ ви, з якими рівень торговельно-економічних відносин кр їни дуже високий ( осія), високий ( ілорусь, 3 хст н, олдов , зерб йдж н) т порівняно невисокий ( ірменія, джикист н, иргист н). н чне перев ж ння імпорту тов рів $3 \mathrm{kp} \mathrm{їн} \mathrm{(див.} \mathrm{рис.} \mathrm{1)} \mathrm{н} \mathrm{д} \mathrm{пок} \mathrm{зник} \mathrm{ми} \mathrm{експорту} \mathrm{(с} \mathrm{льдо} \mathrm{зовнішньо-}$ торговельного обігу ст новить - 7,9 млрд дол. ) зумовлене перев гою імпортних н дходжень 3 осї̈ (83,1 \% серед кр їн і $36,5 \%$ серед кр їн світу), зокрем постійним підвищенням ціни $\mathrm{H}$ російський г 3. кож $\mathrm{H}$ осію прип д $\epsilon$ високий пок зник укр їнського експорту тов рів (71,6 \% серед кр їн і 26,1 \% від 3 г льного пок зник ). стк експорту т імпорту тов рів і послуг осії до кр їни у 2010 р. ст новил 3,1 і 4,9 \% від з г льного пок зник, серед кр їн $-38,7$ і $44 \%$, з йм ючи лідируючі позиції. зн чимо, що зрост ння пок зник торговельного обігу між двом кр їн ми впродовж ост ннього десятиліття з безпечене здебільшого укр їнським експортом до осії, який уже збільшився в чотири р зи. тже, осія є н йбільшим торговельним п ртнером кр їни, головно, з вдяки високій з лежності н ціон льної економіки від російських енергоносіїв т зн чного ринку збуту для кр їни, дже обсяг експорту (13,4 млрд дол. ) укр їнських тов рів лише до осії був дещо виший (13,0 млрд дол. від обсягу експорту тов рів до 27 кр їн крім енерго- 
носіїв, у осії кр їн з куповує руди кольорових мет лів, деревину, тк нини, обл дн ння, в нт жівки тощо, прод є прок тне, гірничош хтне т енергетичне обл дн ння, тепловози, з лізну т м нг нову руду, кокс, прок т чорних мет лів, т кож продовольчу продукцію - цукор, соняшникову олію, м’ясо, плодоовочеві консерви, лкогольні н пої тощо.

ідирюючі позиції у структурі експорту укр їнських тов рів з йм є продукція м шинобудівної г лузі $-34,4 \%$, в той ч с як н йбільш ч стк імпорту в кр їну 3 осії прип д є н енергоносії-76\%.

структурі експорту тов рів н йв гомішими у 2009 р. і 2008 р. були т кі групи (ч стк в з г льному обсязі експорту кр їни) [4]: продукція м шинобудув ння - 34,4 і $39,4 \%$; продовольч продукція - 19,0 і 24,4 \%; продукція мет лургійної промисловості - 16,3 і 12,2 \%; продукція хімічної промисловості - 9,7 і 7,8 \%. структурі імпорту тов рів: - енергоносії - 61,9 і 44,7 \%; продукція хімічної промисловості - 10,5 і 10,2 \%; продукція м шинобудув ння - 10,7 і 20,3%; продукція мет лургійної промисловості - 6,1 i $14,0 \%$.

н ліз розвитку укр їнсько-російських відносин протягом ост нніх років свідчить про те, що економічн співпр ця між кр їною і осією успішно розвив л ся, незв ж ючи н певні проблеми в політичній скл довій цих відносин. е, зокрем , з свідчує зрост ння обсягу торговельного тов рообороту між двом кр їн ми м йже вдвічі - 3 20,3 млрд. дол. $\quad$ у 2004 р. до 39,8 млрд. дол. $\quad$ - у 2008 р., проте у 2010 р. цей пок зник дещо знизився і ст новив - 35,6 млрд. дол.

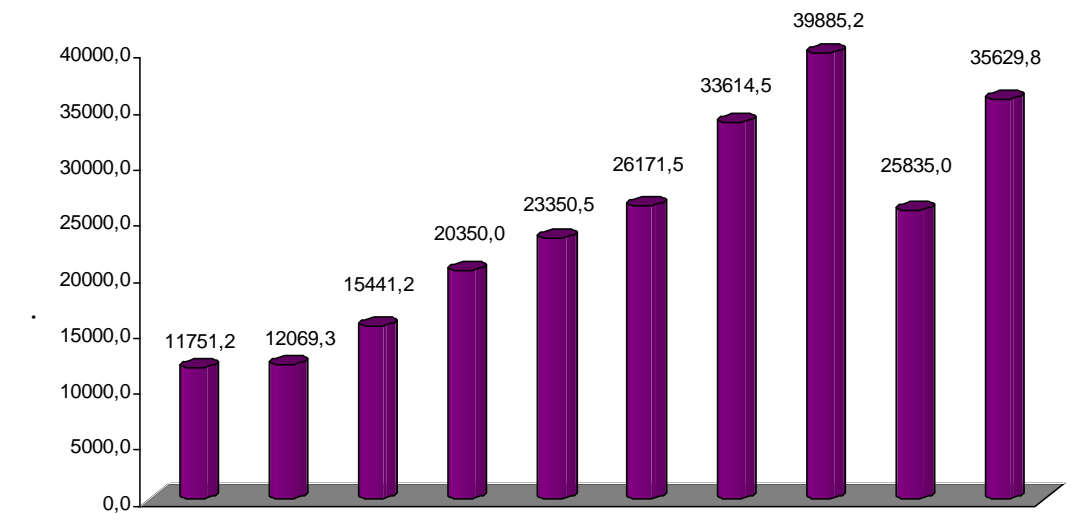

ис. 4. овнішньоторгівельний оборот кр їни з у 2001-2010 pp.

ротягом ост нніх років осія 3 лиш ється основним торговельним п ртнером кр їни серед кр їн і д лекого з рубіжжя. підсумк ми 2010 р., ч стк осії у з г льному зовнішньоторговельному обігу кр їни перевищує $32 \%$ к кщо 1998 р. ч стк тов рообороту з осією у сукупному тов рообороті кр їни ст новил 45,8\%, то 2006 р. цей пок зник уже був нижчим з $29 \%$, в 2010 р. $-31,7 \%$. к тенденція пов'яз н 3 певною геогр фічною диверсифік цією укр їнського експорту.

зн чимо, що кр їн для осії є п'ятим з зн ченням торговельним п ртнером.

стк кр їни в з г льному торговельному обігу осії з 2010 р. ст новил $6,2 \%$. цим пок зником кр їну випередж ють лише ит й $(10,1 \%)$, імеччин $(8,7 \%)$, т лія $(5,4 \%)$, ідерл нди $(8,5 \%)$ тощо. 
бсяги імпорту з осії до кр їни з період 1996-2010 рр. поступово знижув лися. кщо у 1996 р. н ринок кр їни прип д ло пон д 50 \% збуту російських тов рів і сировини, то 2010 р. - лише 36,5\%. кр їн т кож поступово втр ч є позиції н російському ринку, про що свідч ть пок зники експорту, точніше, їхній переп д з 38,7\% у 1996 р. до 17,8 \% у 2002 р. і под льшим поступовим збільшенням до 25,7 \% у 2007 р. i $26,1 \%$ y 2010 p.

сфері торгівлі послуг ми осія т кож виступ є основним торговельним п ртнером кр їни. підсумк ми 2010 р. експорт послуг до осії ст новив 48,3,7 \% від усього експорту послуг, імпорт, відповідно, $-14,5 \%$. озитивне с льдо у торгівлі послуг ми 3 осією ст новило у 2010 р. пон д 4,3 млрд дол. , з г лом з кр їн ми 4,6 млрд дол. зн чимо, що ст більно високе позитивне с льдо у торгівлі послуг ми 3 осією д є змогу кр їні зн чною мірою компенсув ти тр диційно від'ємне с льдо тов рної торгівлі.

одо інвестиційної діяльності між кр їною т осією, ст ном н поч ток 2010 p. осія 3 обсяг ми прямих інвестицій в кр їну посід є четверте місце серед 125 кр їнінвесторів [4]. осійськ едер ція інвестув л в економіку кр їни 2 674,6 млн дол. що ст новить $6,7 \%$ від з г льного обсягу прямих іноземних інвестицій, з лучених до укр їнської економіки. території кр їни пр цює 2379 підприємств з російським к піт лом. рямі інвестиції з кр їни в осійську едер цію ст ном н цей період ст новили 165,5 млн дол. зн чимо, що осія після іпру $(22 \%)$, імеччини (15\%) т ідерл ндів (10\%) посід є четверте місце з обсяг ми інвестицій в укр їнську економіку. е 3 402,8 млн дол. бо 7,6 \%, т кож, друге місце після іпру (92,6 \%) 3 н дходженнями інвестицй 3 кр їни - 181,9 млн дол. , бо 2,7\%.

ілорусь, 3 хст н т зейб рдж н посід ють н ступні три місця після осії серед кр їн $\quad 3$ обсягом торгівлі (3,9, 1,8 і 1,4 \% серед кр їн світу). ілорусь н укр їнський ринок пост ч є верст ти, в нт жівки, тр ктори, продукцію легкої промисловості тощо. кспорт до ілорусі - це прок т чорних мет лів, верст ти т обл дн ння, цукор, олія тощо. ілоруссю і зерб йдж ном кр їн м $є$ нег тивне с льдо зовнішньоторговельного б л нсу з огляду н тов рну скл дову, зокрем , $з$ купівлю кр їною в зерб йдж ні енергоносіїв, проте з рештою кр їн ередньої зії т к вК ззя, н вп ки, - позитивне. кспорт до цих регіонів формують т кі тов ри, як прок т чорних мет лів, обл дн ння, промислові тов ри широкого вжитку, мет лоріз льні верст ти, цукор, борошно; імпорт - г з, руди кольорових мет лів, б вовн , тк нини тощо.

еред торгових п ртнерів кр їни у 2010 р. ілорусь посід л друге місце серед кр їн (після ) т п’яте місце серед кр їн світу (ч стк ілорусі у з г льному тов рообігу кр їни з кр їн ми світу ст новить 3,9 \%). восторонне торговельно-економічне співробітництво між кр їною т ілоруссю з ост нні роки дин мічно розвив лось і м ло перспективи под льшого розвитку, ле під нег тивом фін нсово-економічної кризи у 2009 р. відбулося зменшення обсягів двосторонньої торгівлі.

2010 р. $з$ г льний тов рообіг кр їни 3 ілоруссю ст новив 4 661,71 млн. дол. і збільшився порівняно з 2009 р. 1 581,82 млн дол. г льний експорт тов рів і послуг ст новив 2030,87 млн дол., в тім числі тов р ми 1899,2 млн дол. $(93,5 \%)$. г льний імпорт тов рів і послуг з еспубліки ілорусь в кр їну ст новив 2630,84 млн дол. і збільшився у порівнянні з 2009 р. н 894,71 млн дол. тім числі тов р ми ст новив 2 567,59 млн дол. $\quad$ (97,5\%) і збільшився порівняно 3 2009 р. н 874,76 млн дол. ег тивне с льдо ст новить 599,97 млн дол. 
сновними ст ттями експорту з цей період до ілорусі з лиш ються (від з г льного обсягу експорту тов рів) продукція: мет лургійної промисловості (чорні мет ли, труби, фероспл ви, плоский прок т) - 26,7 \%; м шинобудув ння (мех нічне обл дн ння, електричні м шини, в нт жівки) - 19,8\%; гропромислового комплексу - 21,5\%; хімічної промисловості (шини, пл стм с , ф рб , полімери) - 11,1\%. сновними ст ттями імпорту в кр їну з цей період є: енергоносії-60,0 \% (від з г льного обсягу імпорту тов рів); продукція м шинобудув ння (тр ктори, в нт жівки, холодильники, побутові прил ди) - 13,7 \%; продукція хімічної промисловості (ф рм цевтику, полімери, добрив ) - 10,9 \%; мет лургійн продукція (троси, к н ти) - 4,2 \%; продукція $-4,1 \%$

п р метр х торгівлі кр їн позн ч ються позитивні чинники - н явність історично н л годжених тов ропотоків т потенці лів спеці лізов ного виробництв, коопер ційні тенденції, т кож нег тивні - зобов'яз ння перед осією в р мк х итного союзу, пр ктик спеці льних под ткових зборів тощо.

поч ток 2011 р. ілорусь інвестув л в економіку кр їни 43,74 млн дол. що ст новить $0,1 \%$ у з г льному обсязі прямих іноземних інвестицій в економіку кр їни. 2010 р. відбувся приріст білоруських інвестицій, обсяг якого ст новив 5 880,3 тис. дол. . промисловість кр їни з лучено білоруських інвестицій обсягом 19,29 млн дол. (44,1\% від з г льного обсягу білоруських інвестицій в економіку кр їни). економіку ілорусі резидент ми кр їни інвестов но 4,09 млн дол.

що ст новить $0,1 \%$ від 3 г льного обсягу інвестицій з кр їни. ротягом 2010 р. відбувся відтік інвестицій з кр їни до ілорусі обсягом 644,3 тис. дол.

еред торговельних п ртнерів кр їни 3 xcm н, 3 д ними 2010 р. посід є третє місце серед кр їн $\quad$ т 11 місце серед усіх торговельних кр їн-п ртнерів кр їни. 2010 р. зовнішньоторговельний обіг тов р ми т послуг ми кр їни 3 з хст ном ст новив 2 170,87 млн дол. $\quad$ і зменшився порівняно з 2009 р. н 1 408,01 млн. дол.

бо н 39,3\%, в тому числі тов р ми ст новив 2 066,72 млн дол. $\quad(95,2 \%)$ і зменшився порівняно з 2009 р. н 1 385,65 млн дол. . ри цьому: з г льний експорт тов рів т послуг ст новив 1 382,6 млн дол. , в тім числі тов р ми - 1300,51 млн дол.

; $з$ г льний імпорт тов рів т послуг з в кр їну ст новив 788,27 млн дол., в тому числі тов р ми ст новив 766,22 млн дол. ; позитивне с льдо ст новило 594,33 млн дол.

обсяг ми тов рообігу кр їн посід є третє місце після осії т збекист ну, серед кр їн , і п’ятн дцяте - серед 148 кр їн-торгових п ртнерів 3 хст ну. обсяг ми експорту кр їн посід є четверте місце після осії, ит ю т імеччини. кp їн які кр їн експортер простежен в 62 з 142 основних тов рних груп. к і р ніше, у структурі укр їнського експорту перев ж ють м шини, уст ткув ння і з пч стини до них, продукти х рчув ння.

труктур укр їнського експорту до еспубліки 3 хст н (ч стк в 3 г льному обсязі експорту кр їни) є т кою: продукція - ст новил 13,9\%); продукція н фтохімічної промисловості - 2,8 \%; продукція деревообробної промисловості - 5,0 \%; продукція мет лургійної промисловості - 13,0 \%; продукція м шинобудув ння - 26,4 \%; різне $-1,2 \%$. кр їн імпортув л (ч стк в 3 г льному обсязі імпорту кр їни): енергоносії - 64,8 \% (дизельне п ливо $(17,8 \%)$, к м'яне вугілля $(9,8)$, бензин $(6,7)$, м зут $(3,0)$, н фт $(0,001))$; продукція мет лургійної промисловості - 17,1 \% (цинк необроблений $(2,8 \%)$, прок т плоский $(2,3)$, фероспл ви $(0,8))$; продукції н фто-хімічної промис- 
ловості - 2,3\% (фосфін ти (10,8\%), продукти неорг нічної хімії $(0,3 \%))$; різне - 7,8 \%, с ме: 6 вовн $(7,7 \%)$, текстиль $(7,1 \%)$.

оргівля кр їни 3 з хст ном здебільшого визн ч ється ст тусом обох кр їн щодо енергоз безпеченості. 3 хст н, н відміну від кр їни, є здебільшого експортером енергоносіїв, причому с ме торгівля ними у попередніх рок х з безпечув л 3 хст ну з г льне позитивне с льдо у торгівлі з кр їною.

йбільшими торговельними п ртнер ми 3 хст ну 3 пок зник ми експорту є: т лія, ит й, осія, р нція, встрія. мпорту - осія, ит й, імеччин, кр їн , еликобрит нія, , т лія тощо.

2010 р. як торговельний п ртнер кр їни зерб йдж н посід є четвере місце серед кр їн . кр їн серед кр їн перебув $\in$ н другому місці з експорту тов рів в зерб йдж нську еспубліку, п’яте місце серед усіх кр їн світу, 3 пок зник ми імпорту з зерб йдж ну - шосте місце.

г льний тов рообіг у 2010 р. ст новив 1,6 млрд дол. . торгівлі тов р ми кр їн з зерйб дж ном м є від'ємне с льдо, яке ст новило 340,3 млн дол.

торгівлі послуг ми - дот тній (12,2 млн дол. ). кспорт укр їнських тов рів ст новив 610,8 млн дол. оловно, це продукція мет лургійної промисловості, гропромислового комплексу т м шинобудув ння. мпорт продукції ст новив 951,1 млн дол.

е бул головно продукція п ливно-енергетичного комплексу, як ст новил близько $95 \%$ від з г льного обсягу імпорту. рім продукції групи енергоносіїв, в кр їну здійснюв ли пост вки поліетилену, кр нів, іншої м шинобудівної продукції, виробів легкої промисловості (б вовняне волокно, прядиво), пл стм су, пл стм сових виробів, тютюнову сировину, овочів і соків.

зерб йдж н є одним 3 н йв жливіших торговельних п ртнерів кр їни, що зн чною мірою пов'яз но з розробленням цією кр їною великих покл дів н фти у спійському шельфі. купівля н фти може "пог ш тися" кр їною зворотним потоком продукції вітчизняної промисловості т сільського господ рств . ля того щоб з цік вити зерб йдж н у н рощув нні обсягів пост вок сировини, яку будуть тр нспортув ти територією н шої кр їни, кр їн н д сть зерб йдж ну $50 \%$ знижки н розв нт ження н фти. е рішення з фіксов но відповідною угодою з урядом зерб йдж ну щодо співробітництв у сфері тр нспортув ння н фти територією кр їни. год передб ч $є$ тр нспортув ння до 3 млн т зерб йдж нської н фти внутрішніми м ршрут ми н рогобицький і двірнянський н фтопереробні з води, т кож до 5 млн т у 3 хідному н прямі т до 12 млн т ун прямі ілорусі [2].

орівняльний н ліз укр їнського експорту пок зує, що укр їнські виробники н рощують пост вки тов рів 3 тр диційно уст вленими позиціями мет лургійної промисловості й гропромислової групи. г лом, з вид ми продукції і н д нням послуг, $€$ зн чн перспектив в розвитку чинного співробітництв в космічній т ві ційній г лузях, н уково-технічній сфері.

2010 р. зерб йдж нськ еспублік інвестув л в економіку кр їни 31727,7 тис. дол. нвестиції зерб йдж ну н дійшл в т кі г лузі, як переробн промисловість - 30,0 \%, будівництво - 29,9 \%, від з г льного обсягу інвестицій зерб йдж ну в економіку кр їни.

бсяг тов рообігу між кр їною т олдовою (з ур хув нням д них ридністровського регіону) у 2010 р. ст новив 787,16 млн дол. $\quad$, що н 5,5\% більше, ніж 2009 р. 2010 р. обсяги імпорту з кр їни в олдову ст новили 528,5 млн дол. 
що н 15,2\% більше, ніж 2009 р., обсяги експорту тов рів 3 олдови в кр їну 91,6 млн дол. що н 12,6\% більше, ніж 2009 р.

н ліз розвитку торговельно-економічних зв'язків між кр їною т олдовою у 2010 р. 3 свідчує, що кр їн впевнено 3 йм є одну з провідних позицій серед торговельних п ртнерів олдови. окрем , 3 підсумк ми 2010 р. кр їн посід є друге місце 3 обсяг ми імпорту в олдову і третє (після осії т умунії) 3 обсяг ми тов рообігу серед кр їн, які здійснюють зовнішньоторговельну діяльність 3 олдовою.

зн чимо, що у 2010 р. кр їн поступил ся осії першим місцем 3 обсяг ми імпорту, н с мперед, з вдяки монопольним пост вк м з цієї кр їни природного г зу до олдови. більшення імпорту з олдови до кр їни (н 12,6 \%, 3 д ними молдовської ст тистики, і н 41,5 \%, з д ними укр їнської ст тистики) пояснюють переорієнт цією молдовських тов ровиробників н ринки кр їн ун слідок скорочення пост вок до кр їн , і передусім до умунії.

д ними ціон льного бюро ст тистики еспубліки олдов , у 2010 р. обсяг тов рообігу між еспублікою олдов (без ур хув ння д них ридністровського регіону) т кр їною ст новив 620,1 млн дол. і збільшився порівняно з 2009 р. н $14,8 \%$. стк кр їни у зовнішньоторговельному тов рообігу олдови у 2010 р. ст новил $11,4 \%$. тже, кр їн посід є друге місце 3 обсягом імпорту в олдову т трете місце (після осії т умунії) з обсягом тов рообігу серед інших кр їн.

зовнішній торгівлі між н шими кр їн ми простежується позитивне торговельне с льдо н користь кр їни у сумі 436,9 млн дол. . . і 37 млн дол. послуг ми.

2010 р. основними тов р ми укр їнського експорту були: н фтопродукти, вугілля, дроти ізольов ні, мет лопродукція, труби, медик менти, шокол д, хлібобулочні т тютюнові вироби. н чну ч стку в укр їнських пост вк х т кож з йняли лісом тері ли т меблі. сновною ст тею молдовського експорту до кр їни у 2010 р. $з$ лиш ється вино, ч стк пост вок якого ст новил $14,5 \%$. рім того, зн чну ч стку в 3 г льних молдовських пост вк х до кр їни з йм ють етиловий спирт, н сіння соняшнику т медик менти: 8,0 \%, 6,6 т 6,0 \%, відповідно, від з г льних обсягів експорту з олдови до кр їни. ри цьому, обсяги пост вок вин зросли н 63,0 \%, етилового спирту - у 2,1 р 3, н сіння медик ментів - н 57,7 \%. н чну питому в гу у молдовських пост вк х до кр їни з йм ють т кож: олія - 4,7 \%, соки фруктові - 3,5\%, ч стини для втомобілів - 3,3 \%, прутки з нелегов ної т легов ної ст лі - 3,3 \% т 2,5\% відповідно, килими $-2,6 \%$, тютюн необроблений $-2,6 \%$ тощо.

порівнянні до 2009 р. простежено різке п діння обсягів експорту в олдову т ких тов рів: борошн - н 23,6 \%, зерн - м йже н 43,0 \%, бобів соєвих - у 9,0 р зів, води - м йже н 7,0 \%, пив - н 41,2 \%, цементу - н 38,1 \%, г зів н фтових - н 18,8 \%, труб. днією з причин з зн ченого, може бути зменшення купівельної спроможності н селення олдови у 2010 р. і, відповідно, п діння рівня спожив ння. голосимо т кож н відсутності пост вок до олдови укр їнської електроенергії, обсяги експорту якої у 2008 р. сяг ли 14,0 \% від з г льних обсягів укр їнських пост вок до кр їни. е пояснюють пост вк ми електроенергії до олдови з олд ( ридністров’я) відповідно до укл деного молдовською стороною контр кту з цією комп нією.

езн чні обсяги торгівлі кр їни з джикист ном пояснюється не лише геогр фічною відд леністю т сл бким рівнем економічного розвитку цієї кр їни, й військовими діями, міжетнічними конфлікт ми н її території н поч тку 90-х років ст. 
2010 р. у торгівлі тов р ми простежено позитивне с льдо, яке ст новило 71,2 млн дол. , відповідно, у торгівлі послуг ми - 3,0 млн дол.

структурі укр їнського експорту тов рів до джикист нуз 2010 р. перев ж ли: продукція м шинобудув ння; тр ктори т 3 пч стини до них; чорні мет ли т вироби з них; ф рм цевтичні продукти; корунд штучний; кондитерські вироби, соки, води; п пір, к ртон і вироби з нього. еред імпортов них кр їною тов рів 3 джикист ну у 2010 р. були провідними: 6 вовняне волокно т б вовняні вироби; їстівні плоди, горіхи т овочі тощо.

озвиток торговельно-економічного співробітництв між кр їною і уркменіст ном посід є в гоме місце у відносин х між двом кр їн ми. ого н прями у 2010 р. поляг ли, зокрем , у співробітництві у п ливно-енергетичній т інвестиційно-будівельній сфер х, військово-технічному співробітництві, т кож співпр ці н міжрегіон льному рівні. одо будівництв , то з зн чимо, що протягом 2009-2010 років укр їнські комп нії н д лі ре лізув ли в уркменіст ні низку будівельних проектів з г льнодерж вного призн чення, зокрем , їм вд лося з вершити будівництво з лізничного мосту через муд р'ю т мур т- еркичі, відновити будівництво тунелю в шг 6 ті, т кож розпоч ти будівництво втомобільного мосту.

овнішньоторговельний обіг тов рів і послуг кр їни з уркменіст ном у 2010 р. ст новив 331,9 млн дол. $\quad$ і зменшився порівняно з пок зником 2009 р. н 71,03 млн дол.

(н 17,6 \%). меншення зовнішньо-торговельного обігу відбулося з вдяки скороченню обсягів експорту н 72,9 млн дол. (н 18,5\%) під ч с одноч сного збільшення імпорту тов рів і послуг н 1,94 млн дол. (н 20\%). озитивне с льдо зменшилося порівнянні з 2009 р. н 74,9 млн дол. (н 19,5 \%) т ст новило 308,94 млн дол.

сновними ст ттями експорту до уркменіст ну у 2010 р. 3 лиш л ся продукція (від з г льного обсягу експорту тов рів): мет лургійної промисловості- 39,5\%; гропромислового комплексу - 30,7 \%; м шинобудув ння - 14,3 \%; хімічної промисловості - 6,2\%. мпорт тов рів 3 уркменіст ну в кр їну в 2010 р. охоплюв в: продукція легкої промисловості, де перев жн ч стк прип д є н експорт б вовни; продукція хімічної промисловості тощо. бсяги імпорту продукції гропромислового комплексу, м шинобудув ння т мет лургійної продукції не є суттєвими, упродовж 2010 р. зменшув лися.

ерез зн чне зменшення обсягів експорту продукції мет лургійного комплексу т м шинобудув ння у 2010 р. відбулося скорочення двосторонньої торгівлі тов р ми між кр їною т уркменіст ном. тже, двостороння торгівля тов $\mathrm{p}$ ми ще не відповід $\epsilon$ економічним потенці л м обох кр їн. уркменіст н потребує збільшення обсягів пост вок трубної продукції укр їнського виробництв, продукції м шинобудівного комплексу, хімічної т х рчової промисловості.

2010 р. простежено зн чне зрост ння з г льного обсягу послуг між кр їною т уркменіст ном (н 56 \%), який ст новив 118,7 млн дол. , при цьому експорт послуг дорівнюв в 111,51 млн дол. (зрост ння н 43,25 млн дол. бо н 63,4 \%), імпорт - 7,22 млн дол. (зменшення н 0,61 млн дол. бо н 7,7 \%). сновними позиціями експорту послуг до уркменіст ну були будівельні послуги; різні ділові, професійні т технічні послуги; послуги в рхітектурних, інженерних т інших технічних г лузях; подорожі; тр нспортні послуги; держ вні послуги, які не н леж ть до інших к тегорій. сновними позиціями імпорту послуг з уркменіст ну були: тр нспортні послуги; подорожі; держ вні послуги, які не віднесені до інших к тегорій. 
ке збільшення двосторонньої торгівлі послуг ми відбулося, н с мперед, з вдяки будівництву.

2010 р. 3 г льний обсяг інвестицій $з$ уркменіст ну в кр їну ст новив 495,2 тис. дол. т збільшився порівняно з 2009 р. у 2,8 p. нвестиції з лучені в оптову торгівлю і посередництво в торгівлі - 489,9 тис. дол.

$(98,9 \%), \quad$ т кож переробну промисловість. нвестиції з кр їни в економіку уркменіст ну в 2009 р. ст новили 49 тис. дол. $\quad$ (д них з 2010 р. нем є). нвестиції з лучені в будівництво.

овнішньоторговельний обіг кр їни 3 збекист ном у 2010 р. ст новив 555,4 млн дол. льдо у торгівлі тов р ми т послуг ми для кр їни було дод тне і ст новило 146,7 і 10,4 млн. дол. структурі укр їнського експорту тов рів до збекист ну перев ж л продукція ф рм ції, чорні мет ли т вироби з них; продукція м шинобудув ння: к $з$ ни, м шини, уст ткув ння. жири т олія, електричні м шини т уст ткув ння; продукція хімічної промисловості: полімерні мет ли, пл стм си, к учук, гум , п пір т к ртон, кер мічні вироби тощо. еред імпортов них кр їною тов рів 3 збекист ну домінув ли добрив ; продукція хімічної промисловості: полімерні м тері ли і пл стм си, б вовн т вироби з неї; продукція гропромислового комплексу: їстівні плоди, горіхи т цитрусові; продукція кольорової мет лургії: цинк т вироби з цинку, н фт бо н фтопродукти (отрим ні з бітомінозних порід (мінер лів), окрім сирих); н земні тр нспортні з соби (окрім з лізничних), тютюн тощо.

збекист н 3 йм є досить ктивну позицію у відносин х 3 провідними кр їн ми світу, передусім із $\quad$, т кож проводить лінію н под льше зближення з кр їн ми вропи, івнічної мерики т понії у військовій т економічній сфері. осід ючи с мостійну вив жену позицію, збекист н з обережністю ст виться до різних проявів н ддерж вності у формув ннях . я кр їн відігр є для кр їни роль льтерн тивного г зпромівського вектор енергопост вок, передусім г зу. ур хув нням розробки н явних перспективних г зових і н фтових родовищ н території збекист ну ця кр їн може ст ти в жливим п ртнером кр їни у вирішенні проблем енергоз безпечення. ж ль, ост точне вирішення цього пит ння г льмув л неконструктивн позиція російських енергетичних структур, що вст новили монопольні, невипр вд но з вищені т рифи н тр нзит центр льно зійських енергоносіїв у треті кр їни [5]. отенці л укр їнсько-узбецьких відносин повною мірою ще не ре лізов ний. осить низький торговельно-економічний обіг між кр їн ми.

еспублік збекист н пров дить політику стримув ння інвестув ння в інші кр їни і робить все для з лучення інвестицій. диною інвестицією з боку збекист ну в економіку кр їни є вкл дення коштів у к піт льний ремонт с н торію “ збекист н” в м. лт (близько 2,5 млн дол. ).

иргист ном - м ленькою середньо зійською кр їною, кр їн м є незн чні торговельні конт кти. бсяг тов рообігу між иргист ном т кр їною з 2010 р. порівняно 3 н логічним періодом 2009 р. зменшився н 6,4 млн дол. . окрем , експорт тов рів і послуг скоротився н 8,4 млн дол. , імпорт - збільшився н 2 млн дол. озитивне с льдо ст новило 69,3 млн дол.

сновними ст ттями експорту у 2010 р. бул продукція (від з г льного обсягу експорту тов рів): гропромислового комплексу - 65,9\%; м шинобудув ння - 9,3\%; хімічної промисловості - 9,5 \%; мет лургійної промисловості - 2,5 \%. мпорту, відповідно бул продукція гропромислового комплексу - 49,0\%; п ливо-енергетичного комплексу - 27,7 \%; м шинобудув ння - 17,0 \%; легкої промисловості - 4,2 \% тощо. мпорт продукції гропромислового комплексу з 2010 р. порівняно з 2009 р. збільшив- 
ся у дв р зи (+1,52 млн дол. ) з р хунок збільшення імпорту овочів і бобових н

0,23 млн дол. й тютюнової сировини н 94,7\% (+1,28 млн дол. ).

бсяги експортно-імпортних опер цій між кр їною т ірменією є незн чними і в 2010 р. ст новили 238,7 млн дол. . озитивне с льдо зовнішньоторгівельного обігу ст новило 189,1 млн дол. у торгівлі тов р ми - 183,3 млн дол. , випередж ючи т кі кр їни , як джикист н і иргист н. кр їн прод є ірменії деякі види мет локонструкцій, труби, лкогольні н пої, етиловий спирт, електричні м шини, незн чні обсяги продукції хімічної промисловості. упує симетричні види продукції мет лургії, мет лообробки т м шинобудув ння, синтетичний к учук, тр диційні вірменські лкогольні н пої тощо.

співробітництві кр їни з кр їн ми необхідно розширюв ти коопер ційні зв'язки. ерспективними г лузями з коопер ції можуть ст ти: ві ційн , військовотехнічн , м шинобудівн (з осією, олдовою, збекист ном), теле- і р діо п р тури (з ілоруссю), текстильн т легк промисловість, (з ілоруссю, олдовою, уркменіст ном), ф рм кологічн промисловість (з збекист ном) тощо.

тже, головними н прям ми вдоскон лення зовнішньоторговельної діяльності кp їни є диверсифік ція ринків енергоносіїв т інших стр тегічно в жливих сировинних і м тері льних ресурсів, диверсифік ція експорту вл сної продукції, т кож посилення держ вного регулюв ння зовнішньоторговельного б л нсу для зменшення п сивного с льдо.

1. ерж вний комітет ст тистики кр їни. ежим доступу до джерел : http://www.ukstat.gov.ua 2. кр їн зробить н фтову знижку зерб йдж ну // кономічн пр вд . ежим доступу до джерел : http://www.epravda.com.ua

3. итн служб еспубліки олдов . ежим доступу до джерел : http://www.coustoms.gov.md 4. іністерство економічного розвитку і торгівлі кр їни. ерж вн підтримк кр їнського експорту. ежим доступу до джерел : http://www.ukrexport.gov.ua

5. ек ленко . . овнішня політик кр їни. ежим доступу до джерел :

http://pidruchniki.ws/18000102/politologiaa/respublika uzbekistan

$$
\text { m ття: н дійшл до редколегії 17.11.2011 }
$$

прийнят до друку 30.11.2011

\title{
THE DYNAMICS AND THE CURRENT STATE OF TRADE AND ECONOMIC TIES BETWEEN UKRAINE AND CIS COUNTRIES HAS BEEN ANALYSED
}

\author{
N. Gasuliak \\ Ivan Franko National University of Lviv, \\ . Doroshenko St., 41, UA - 79000 Lviv, Ukraine
}

The main parameters, structural features, geographical areas of foreign trade relations of Ukraine with the CIS countries has been reviewd, as well as the main problems in the framework of cooperation between Ukraine and these countries has been highlighted.

Ke ywords: CIS countries, trade and economic relations, trade in goods, trade in services, volume of exports, imports, trade, balance of foreign trade in goods and services, investments. 


\section{C} :

\section{- суляк}

ьвовский н цион льный университет имени в н р нко, ул. . орошенко, 41, г. ввов, 79000, кр ин

ро н лизиров н дин мику и современное состояние торгово-экономических связей кр ины из стр н ми . ссмотрены гл вные п р метры, структурные особенности, геогр фические н пр вления розвития внешнеторговых связей кр ины со стр н ми, , т кже выделены гл вные проблемы в р мк х сотрудничеств кр ины с этими стр н ми.

лючевые слов : стр ны-уч стницы , торгово-экономические связи, торговля тов р ми и услуг ми, инвестиции. 